\title{
Combining Problem Based Learning and Activism in a Feminist Classroom
}

\author{
Beth Williford*
}

This article explores my experience of incorporating a multi-stage Problem-Based Learning (PBL) project in an undergraduate women's studies course. PBL is a pedagogical approach that uses real open-ended problems of the social world as a basis for students to collectively consider and address. Incorporating an activist element as a final stage serves to connects classroom learning to the world students inhabit, provide them with a chance to direct their own learning, and motivate them with tools to address inequality, thus inspiring their own activism. PBL shares important characteristics with feminist pedagogy and I argue that this pedagogical approach allows instructors to integrate the benefits of community engagement and feminist pedagogy to increase student learning and commitment to action. I adopt a reflexive approach to examine student responses and my own from this project. I note four themes from students that include attention to the collaborative process and collective ownership, being empowered to act, focusing on solutions for the community, and a greater knowledge of the problem and connection to the women's studies discipline. Finally, I offer a few considerations for instructors interested in incorporating problem based learning with an activist component in a future course. [Article copies available for a fee from The Transformative Studies Institute. E-mail address: journal@transformativestudies.org Website: http://www.transformativestudies.org (C2015 by The Transformative Studies Institute. All rights reserved.]

KEYWORDS: Problem-Based Learning, Social Activism, Feminist Pedagogy.

\footnotetext{
* Beth Williford, Ph.D., is an Assistant Professor of Sociology at Manhattanville College in Purchase, NY. Beth holds a Ph.D. in Sociology from Purdue University. Her primary areas of interest are transnational movements, globalization, indigenous peoples, gender and social justice. Acknowledgements: An earlier version of this paper was presented at the 2011 Southern Sociological Society Annual Meeting. I'd like to thank Bob Perrucci and Mangala Subramaniam for comments on drafts of this paper. Address correspondence to: Beth Williford, Manhattanville College, 2900 Purchase Street, Purchase, NY 10577; e-mail: Beth.Williford@mville.edu.
} 